Acta Universitatis Nicolai Copernici • Pedagogika XXVIII/2012

Nauki Humanistyczno-Społeczne • Zeszyt 405

Magdalena Kujawa

Urząd Miasta Torunia

\title{
TEATR NIEdOSKonAeOŚCI, CZYLI ZAPIS ZASAD ANDRZeja WoJcIEchoWSKIEgo
}

Tie zawsze się z nim zgadzam. Często dyskutowałam z tym, co mó1 wił, a niekiedy jego poglądy budziły mój sprzeciw. W kwestiach zasadniczych jednak tworzony przeze mnie teatr $\mathrm{z}$ osobami niepełnosprawnymi wyrasta wprost z zasad, które ustanowił Profesor Andrzej Wojciechowski.

\section{U SIEBIE}

Atmosfera pełna spontanicznej radości oraz akceptacji - to zapamiętałam z pierwszego mojego pobytu w założonej przez Profesora Pracowni Rozwijania Twórczości Osób Niepełnosprawnych. Być może właśnie ten element sprawił, że jednorazowa wizyta przeciągnęła się na dwadzieścia lat i trwa nadal. Pisząc o akceptacji, nie mam na myśli tylko tego, że osoby niepełnosprawne mają bezpieczne miejsce, w którym czują się lubiane i doceniane. Poczucie akceptacji od pierwszej chwili towarzyszyło również mnie. Przy wejściu otrzymałam pakiet pozytywnej energii, która sprawiła, że zakłopotanie i spięcie towarzyszące wkroczeniu w nowe, nieznane dotąd środowisko, ustąpiły po krótkiej chwili. W ciasnej salce Dworu Artusa, wśród półek uginających się od prac plastycznych, w zapachu farb, w labiryncie stołów i krzeseł, przez 
które trudno się było przecisnąć, a więc w warunkach urągających wszelkim zasadom bhp, poczułam się - jak wszyscy ci, którzy mnie wtedy przyjęli - u siebie. I zostałam.

Przez następne dwadzieścia lat bywałam w wielu placówkach i stykałam się z różnymi metodami pracy z osobami z niepełnosprawnością. Rzadko jednak miałam okazję widzieć, żeby podopieczni, tak bardzo jak w Pracowni, czuli się gospodarzami miejsca oraz autorami swoich działań.

\section{NiE UDAWAĆ}

Zasady, które Profesor wprowadził w Pracowni, najpierw miałam okazję poznać w praktyce, dopiero później w teorii. To dobra kolejność, bo od razu można było się przekonać, że ta droga jest właściwa, że się sprawdza. Jeśli bowiem każdy czuje się gospodarzem miejsca, to znaczy, że ma poczucie bezpieczeństwa i traktowany jest poważnie. Tylko na takim gruncie można zacząć myśleć o rozwoju. Jeśli z uwagą przyglądamy się drugiemu człowiekowi, on być może zechce się otworzyć i pokazać nam swoją bogatą osobowość. Wtedy wystarczy tylko sięgnąć po talenty, które nosi w sobie, i pomóc je rozwinąć. Jeśli atmosfera bezpieczeństwa i akceptacji towarzyszy wskazywaniu właściwej drogi do osiągnięcia celu, jest wielka szansa, że cel ten zostanie osiągnięty i otworzy drogę do kolejnych stopni samodzielności. Ważne jednak, że Profesor nigdy nie zmuszał nas do osiągania celu za wszelką cenę. Nikt tu nie musiał tworzyć fikcyjnych założeń, do których w odpowiednim terminie dopisałby fikcyjne sukcesy lub zatuszował porażki. Praca w tej placówce jest raczej towarzyszeniem w drodze. Poznajemy się wzajemnie, szukamy w sobie tego, co najlepsze i staramy się to wzmacniać. A jednocześnie mamy szacunek dla ograniczeń i słabości i nie zamierzamy udawać, że naszą pracą spowodujemy, iż niepełnosprawny nagle stanie się pełnosprawny, zacznie pracować, zarabiać i wreszcie będzie użyteczny dla społeczeństwa. Wartości naszej pracy szukamy w spotkaniu, dzięki któremu wydobywamy z siebie nawzajem pełnię osobowości. A pomaga nam w tym twórczość - malarstwo, grafika, rzeźba, teatr. W odróżnieniu od sztuki, która ma ambicje dą- 
żenia do doskonałości, my uprawiamy twórczość - czasem potłuczoną i niezgrabną, ale zawsze wyrażającą nas samych i dającą nam radość. Tą radością chcemy się dzielić z innymi.

\section{WOJNA ŚWIATOWA}

Teatr był zawsze moją drogą. Przez pierwszy rok przyglądałam się pracy kolegów, przez następnych kilka czynnie uczestniczyłam w pracach, by w końcu zacząć samodzielnie przygotowywać spektakle.

Mam ogromny sentyment do pierwszych doświadczeń w teatrze. Przygotowywano wtedy Alibabę i 40 rozbójników. Próby polegały na omawianiu z uczestnikami zajęć poszczególnych scen, wskazywaniu na logikę postępowania postaci oraz przyczyny i skutki wydarzeń scenicznych. Potem aktorzy wypełniali sceny swoją improwizacją. Rodziło to mnóstwo zabawnych sytuacji, jak ta z Jurkiem grającym Kassima. Gdy został napadnięty przez zbójców, na premierze zaczął krzyczeć: „Nie tortujcie mnie, nie tortujcie mnie! Co to, druga wojna światowa?!" Zabawnie było patrzeć na widzów, bo niektórzy nie wiedzieli, czy wypada się śmiać. A Jurek był szczęśliwy, że taki dowcip udało mu się wymyślić. Ta spontaniczność dawała aktorom poczucie, że to, co robią, jest ich własne i że mają wpływ na kształt przedstawienia. To realizacja jednej z ważniejszych zasad Profesora - nie dotykać ręki podopiecznego. Dotyczy ona oczywiście samodzielności prac plastycznych, ale w taki właśnie sposób przekładała się na teatr.

\section{NIE ROZLENIWIĆ SIE}

Można by na tym poprzestać. Ale tworzenie pełnych spontaniczności przedstawień w pewnym momencie mogło spowodować rodzaj rozleniwienia i samozadowolenia. A przecież chcieliśmy się rozwijać. Dlatego, kiedy zaczęłam samodzielnie tworzyć teatr, starałam się za każdym razem stawiać aktorom kolejne wyzwanie. Próbowaliśmy różnych form: teatru słowa, pantomimy, animacji, teatru cienia. Oni 
sami tych wyzwań potrzebowali. Któregoś razu, zdaje się po premierze Pana Huczka, ktoś powiedział, że następnym razem mam napisać scenariusz, bo oni chcieliby, jak w prawdziwym teatrze, uczyć się ról na pamięć. I od tej pory pisałam scenariusze. Uczenie na pamięć wychodziło jednym lepiej, innym gorzej, ale z pewnością nie zabiło w aktorach poczucia, że to, co tworzą, jest ich własne. Sądzę, że przesądza o tym dobór literatury (bo nieufna we własne możliwości tworzenia historii, bazuję jednak głównie na cudzych tekstach) oraz metoda dobierania ról.

\section{BAŚNIOWA DOROSŁość}

Pracuję z osobami dorosłymi i choć mają one pewne ograniczenia, zbrodnią byłoby niedostrzeganie ich dojrzałości. Dlatego poszukuję tekstów, które nie będą ich infantylizować i które poruszać będą tematy im bliskie. Nawet jeśli nasze przedstawienia mają nieco baśniowy charakter, zawsze staram się znaleźć opowieści z drugim dnem, w mądry sposób mówiące o człowieku, jego radościach, problemach i ułomnościach. Dlatego wystawiłam Mary Poppins Pameli L. Travers, historię tajemniczej opiekunki do dzieci, której surowość i chłód są tylko przykrywką dla wielkiego serca i olbrzymiej fantazji. Dlatego opowiedzieliśmy widzom o Panu Huczku (na podstawie książki Hannu Mäkeli), małym człowieczku, który mieszka sam w lesie, w dzień śpi, w nocy zaś wychodzi straszyć ludzi, a tak naprawdę jest potwornie samotny i ma gołębie serce. Jego wrażliwość przejawia się m.in. w podlewaniu drzewa syropem, gdy to jesienią zaczyna tracić liście. Galerię niezwykłych typów ludzkich znaleźliśmy w książce Marcello Argillego Bajki na każdy dzień roku. Opowiedzieliśmy o tym, jak na naszym życiem rządzi upływający czas, ruszyliśmy w podróż, spotykając po drodze m.in. niewidomą dziewczynkę, która namówiła niebo, by wróciło na swoje miejsce, gdy temu przestało się chcieć wisieć nad ziemią. Wcieliliśmy się w zwrotnicowego, który miał problem z uciekającym domem oraz mieszkankę pewnej kamienicy toczącą długie rozmowy ze swoją parasolką. O dojrzewaniu i odpowiedzialności pomógł nam opowiedzieć Janusz Korczak w spektaklu Kajtuś czarodziej, na samych siebie 
zaś w krzywym zwierciadle spojrzeliśmy w Brombie i innych na podstawie Macieja Wojtyszki i Domowych duchach na podstawie Dubravki Ugrešić. Wybór lektury zawsze poprzedzała rozmowa z aktorami. Bez ich akceptacji nie byłoby powodu przystąpienia do pracy.

Często spotykałam się z opiniami, że role są świetnie dopasowane do moich aktorów. Mamy na to prostą metodę. To podopieczni sami decydują, która postać podoba im się najbardziej. Jeśli chętnych do jakiejś roli jest więcej, kandydaci dostają do odegrania scenkę i wszyscy oceniamy, kto zrobił to najlepiej. Tylko ciesząc się rolą, aktor będzie chciał wykonać wysiłek, by ją dopracować.

\section{Czasami bunt}

Staramy się pracować nad spektaklem bardzo intensywnie. Czasem muszę być treserem, który stoi z batem i zmusza do wysiłku. Bo w niepełnosprawności można się wygodnie umościć i znaleźć w niej świetne usprawiedliwienie dla bezczynności. Na to nie pozwalam, co czasem rodzi bunt. Ale też nie wyznaczam sobie ani aktorom terminów: wtedy i wtedy musimy przygotować spektakl. Wszyscy staramy się do niego dojrzeć, przegryźć przez treść, znaczenia, formy, poczuć w nich dobrze.

Tak samo jest z nowymi aktorami albo z nawykami aktorów doświadczonych. Próbuję nakłaniać do wysiłku, pokazywać możliwości, ale decyzję o podjęciu wyzwania uczestnik zajęć musi podjąć sam. Ja tylko mogę wskazywać kierunek i udzielać wsparcia. I cierpliwie czekać, nie wyliczając w głowie spodziewanych efektów. Może nigdy nie przyjdą. Co nie znaczy, że straciliśmy czas.

Nasze spektakle nie są doskonałe. Sądząc po przeglądach, w których uczestniczymy (na których notabene coraz więcej i ciekawiej się dzieje), bywają mniej przewidywalne niż inne. Częściej niż u innych dostrzegam drobne niedoskonałości. Ale sądzę, że moi aktorzy mają satysfakcję $\mathrm{z}$ tego, iż bardzo wiele $\mathrm{w}$ tym teatrze zależy od nich, że mogą mówić własnym głosem. I że sukces jest ich zasługą, a wpadki wynikają z ich niedopatrzeń. 


\section{NIE WIEM}

Przez te dwadzieścia lat wszyscy dorośliśmy i dojrzeliśmy w teatrze. Bywały wielkie zwycięstwa i spektakularne porażki. Może powinnam pytać siebie o wymierne efekty swojej i moich aktorów pracy. One są przecież widoczne, ale często w dłuższej perspektywie. Zresztą nie wiem do końca, na ile to, że Ania sama pójdzie do sklepu kupić sobie bułkę, Zosia pamięta o tym, gdzie położyła swój szalik, a Kasia wie, na którym przystanku wsiąść i wysiąść z autobusu to po trosze zasługa teatru. Nie wiem też, jaka byłabym ja, gdybym się z tym miejscem nie zetknęła. Nie muszę tego wiedzieć. Wiem tylko, że chcę nadal być z moimi aktorami, nawet jeśli czasem mnie albo ich ogarnia zniechęcenie. I wiem, że Profesor Andrzej Wojciechowski ma w tym naszym wspólnym trwaniu swój ogromny udział. 